\title{
Building a curriculum materials center from the ground up A practical approach
}

W

hile many large universities boast ample space and hefty budgets for their curriculum materials centers, as a small university with a tight budget, creating Saint Francis University's (SFU) Curriculum Materials Center (CMC) was a process that required creativity, planning, and ingenuity. This article outlines that process. SFU, located in rural Loretto, Pennsylvania, is a small, Catholic university with an FTE of approximately $2,400{ }^{1}$

As the education librarian at SFU, creating a curriculum materials center was a fun, exciting, and challenging opportunity. What began as a credenza full of textbooks and a collection of children's literature has culminated in a well-used space filled with an ample variety of resources that assists our education students in becoming outstanding teachers.

The main objective of CMC is to support the Education Department's goal of providing "an environment for our prospective early childhood, middle childhood, special education and secondary teachers to foster pedagogical skills and showcase talents in practical educational environments."

\section{Weeding, evaluation, and assessment}

My first task in preparing CMC was to evaluate the existing collection. I began by weeding and assessing the current resources. I worked closely with the faculty in the Education Department, as well as with other SFU librarians and staff. Materials were examined and considered for currency, rele- vance to our education curriculum, authority, accuracy, and purpose.

A resource that was invaluable to me was $A$ Guide to the Management of Curriculum Materials Centers for The 21st Century: The Promise and the Challenge, which outlines the standards for curriculum materials centers as defined by ACRL. ${ }^{3}$ CMC is built on these standards.

\section{Resource acquisition}

In 2012 I was awarded SFU's Excellence in Education Grant to develop the CMC collection. This grant, provided through an application process, is given to those who develop innovative academic and educational projects that contribute to raising the profile of the university. This, along with funding provided from the collection development budget, afforded me the opportunity to acquire necessary resources to add to the collection. In purchasing new materials, I considered my Education Department's current curriculum, Pennsylvania State Standards, and federal requirements, such as the Common Core Competencies. State certification requirements are also a very important consideration. Based on these criteria, most of my budget was spent on manipulatives or "activity kits," as we refer to them.

Renee L. Hoffman is associate librarian at Saint Francis University, email: rhoffman@francis.edu

() 2018 Renee L. Hoffman 


\section{Organizing the collection}

A substantial space located on the lower level of the library was dedicated to CMC. This area was repainted in soft yellows, greens and blues, and shelving was rearranged and added for the Big Book collection and print periodicals. Finally, four small tables and chairs, as well as a large area rug purchased at a yard sale, were added.

With the addition of a newly renovated space and the purchase of new materials, organizing the resources was seamless because I had a vision of how I wanted the CMC to ap- Saint Francis University's Curriculum Materials Center. pear and

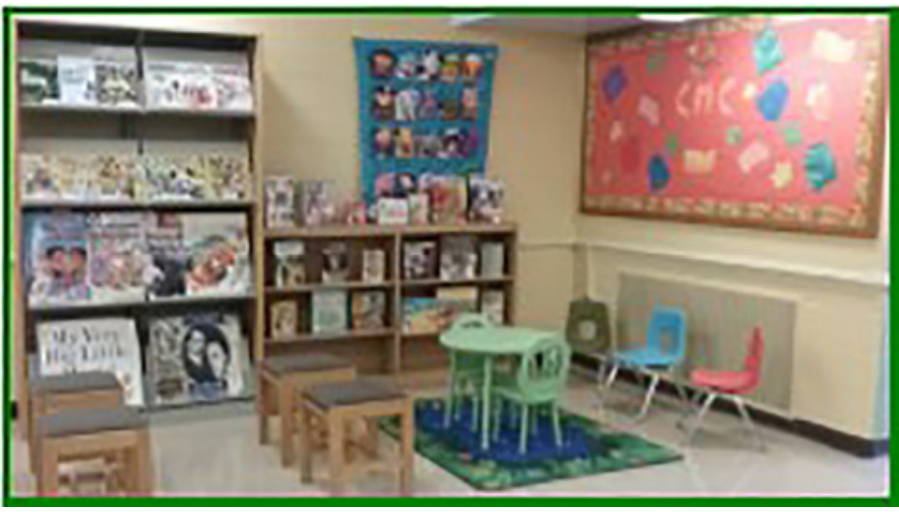

its advantages and disadvantages. Size of the university, the education curriculum, as well as how students will access the CMC resources are important considerations when deciding which organizational method is right for your institution. Each method requires adequate and clear signage. ${ }^{4}$

Organizing our resources by format was the best fit for our institution; therefore, I decided to organize the materials under the folcided to owing six headings: B o o k s, Teachers' Resource Materials (TRM), Activity Kits, Tests, Periodicals, and Electronic Resources. Further, Activity Kits and TRM from multiple sources: my own research, collaboration with SFU education faculty and communication with other education librarians.

Visits to three other curriculum materials centers provided insight and ideas in developing my plan. Seeing other established centers and communicating with seasoned CMC coordinators gave me creative ideas and useful information about acquisitions, cataloging, organization, access, and use of CMC.

There are two main organizational methods for CMC materials: by subject or by format. In organizing the collection by subject area, all formats are contained under one subject heading (i.e., science) and housed together in one shelving location. Such resources may include textbooks, manipulatives, audiovisual materials, trade books, reference books, and periodicals.

Conversely, collections of resources organized by format are shelved by type of material. Either organizational method has are subdivided by these subject areas: communication, early childhood, fine arts, language arts, math, multidisciplinary, science, social skills, and social studies.

First, I reorganized the children's books into four main sections: Children's Literature, Big Books, Juvenile, and Young Adult Literature. We also affixed "J" and "YA" stickers on book bindings, which are color coded with current signage placed in CMC. These modifications have made the collection more browsable and user friendly for students.

Douglas Bleggi, SFU assistant professor of education, has found that:

The literary section in the CMC has been a tremendous success, enabling my classes in middle and secondary education to come alive. My students have immediate and easy access to adolescent literature. While browsing these books, looking for their required reading, they often pick up novels that they may not have chosen. The 
immediate availability has resulted in their reading more selections and at a higher quality level. 5

Next, I created a section for textbooks labeled TRM. I expanded this section by incorporating several volumes from our general collection useful to preservice teachers, such as lesson plans, classroom activity books, worksheets, and test planning materials. Students find browsing the TRM useful when b r a i n $\mathrm{s}$ t o r m ing ideas for lesson planning, creating classroom activities, or incorporating
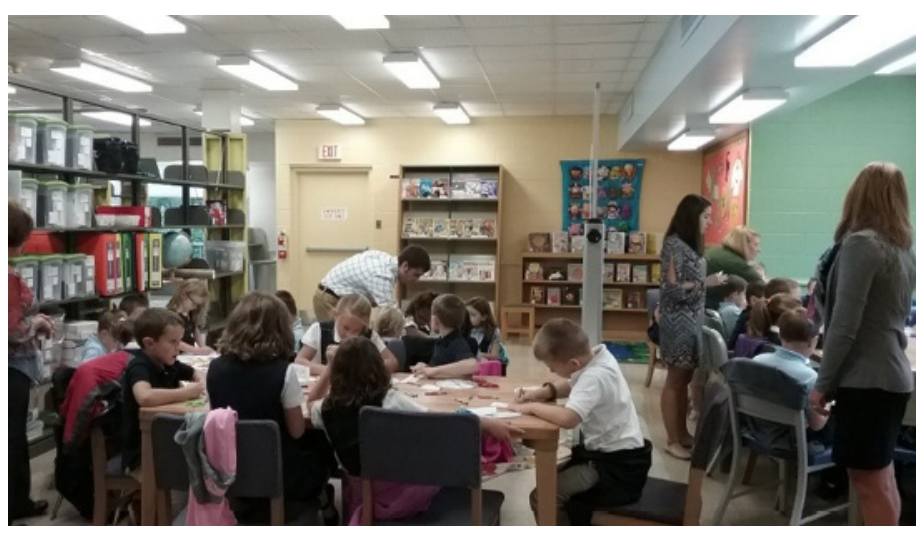

CMC hosts students from local schools. confidence, leading to lessened confusion and deepened understanding. ${ }^{6}$

Additionally, incorporating manipulatives into the curriculum addresses the various multiple intelligences. For example, if students are given the task of learning how to spell, write, and define ten new vocabulary words, all children in the classroom are not going to process and learn these new words in the same fashion.

$\mathrm{L}$ i $\mathrm{n}$ guistically motivated students may excel at this task by using wo od en letter tiles. An aural (auditorymusical) learner may process information most effectively by using a manipulative such as the Go Talk 9, a recording assistive-technology device. Those who learn best by touching (kinesthetic) may enjoy working with flashcards or large paper, markers, and paints to exhibit what they have learned. ${ }^{7}$ Access to CMC has prompted our preservice teachers to use activity kits in their lessons in order to create a more universally designed educational setting that reaches all children in the classroom, regardless of developmental level.

Glenna Zeak, SFU associate professor of early childhood education states that:

The CMC has been an awesome resource for our Education students. The resources have enhanced student ability to plan engaging and appropriate lesson plans and prepare materials which are appealing to children. Opportunities to teach lessons to children in the CMC 
classroom setting have enhanced teaching skills, as the students are observed in action and receive immediate feedback and encouragement. The setting provides opportunities for many diverse and engaging experiences such as muto cultivate excellent teachers. ${ }^{8}$

Although most of our educational periodicals are electronic, we maintain print subscriptions to National Geographic for Kids, Teaching Children Mathematics, and Mathematics Teacher. The periodicals section contains comfortable seating for perusing these print resources. Additionally, I maintain a research guide for CMC containing popular lesson planning websites, certification information, and other useful electronic resources for education majors.

Finally, one of the enclosed study rooms located in CMC was converted into an arts
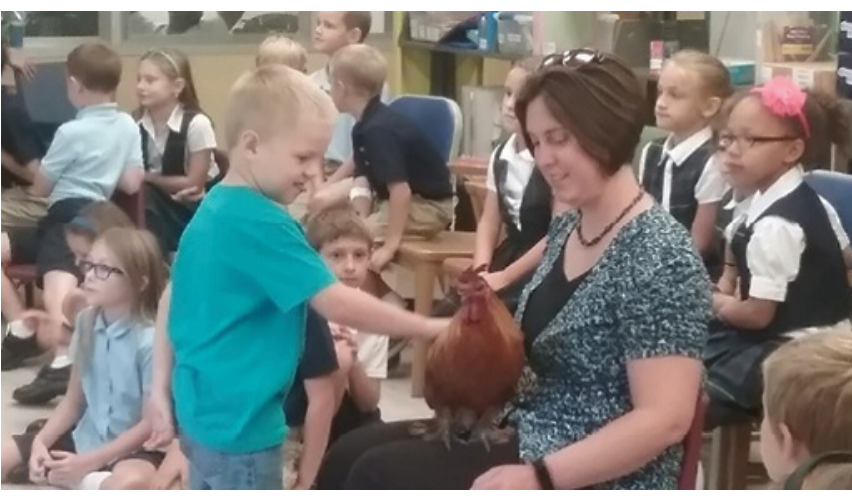

Students learning about biology with Axle Rose, the rooster. munity. the students. sic, art, science and math and helps SFU

yond the boundaries of our campus com-

In 2015, I coordinated "The Literacy Project" in collaboration with Stephanie Ivory, SFU education department chair, and Renee Phister, principal at St. Michael's Catholic School in Loretto, Pennsylvania. Each semester we host students from St. Michael's (grades $\mathrm{K}-4$ ) for a special presentation. Ivory's SFU education preservice teachers participate by devising learning stations relevant to the presentation. They use many of the resources available in CMC to plan, set up, and instruct follow-up lessons for

For example, in 2016, Gail Drus, SFU assistant professor of biology, presented a science lesson about chickens, along with her pet rooster, Axle Rose. At various learning stations, students learned about the life cycle of a chicken and completed math lessons to determine How Many Eggs Are in the Coop? and crafts space for preservice teachers. A Cricut machine, a laminator, and an Ellison machine make this a popular space for creating bulletin boards, portfolios, and lesson plans. The library stocks this area with card stock for the Cricut and Ellison machines, glue sticks, and other arts and crafts materials. Laminating sheets may be purchased at the public services desk for 35 cents.

\section{Community outreach}

According to Nancy Clarke in The Roles and Functions of Curriculum Centers in Australia, "curriculum libraries serve as a place for ... instruction and workshops and as a teaching laboratory." Since its inception in 2012, CMC at our university has grown be-
Finally, students who so desired were given the opportunity to pet Axle Rose.

Ivory has observed that:

The Curriculum Materials Center on the SFU campus has permitted the opportunity for preservice teachers to connect theory to practice. The center provides an environment for upper-level education majors to review and research materials to devise developmentally appropriate activities for young learners. The activities are hands-on, highly engaging activities which promote higher level thinking skills specifically related to the areas of STEAM (science, technology, engineer- 
ing, arts, and mathematics). Students can refine pedagogical skills while interacting with children from a local school. Upon completion of lesson delivery, preservice teachers engage in reflection activities to ensure optimal lesson plan development and delivery. The opportunities extended through the CMC prepare students for the rigor and high expectations for the culminating student teaching experience. ${ }^{10}$

\section{Conclusion}

The creation, development, and maintenance of a curriculum materials center within university libraries is essential to cultivate the skills necessary in preparing preservice teachers for the rigorous demands of a career in the field of education. Support of education faculty, university administration, the library director, and colleagues is necessary for the ongoing success of the center. Knowledge of one's education curriculum, state standards, and certification requirements is essential in the planning and organizing stages, as well as in collection development.

Although budget restraints may be a concern, beginning with one's current resources and growing the collection from there can blossom into a space that greatly enhances the educational experience for preservice teachers.

In addition to the benefits to education faculty and students, the development of the SFU $\mathrm{CMC}$ has been a rewarding experience for me as a librarian. I am able to work more closely with students in a unique and meaningful way, while expanding my knowledge in the field of education. This has prompted me to pursue my bachelor's degree in Early Childhood Education, which has opened up a multitude of fulfilling learning experiences. I hope to continue to develop CMC, as I seek further opportunities for growth and expansion.

\section{Notes}

1. Saint Francis University, "SFU 2017 Fact Book," Saint Francis University web- site, accessed January 15, 2018, https:// my.francis.edu/ICS/Faculty_Staff/Institutional _Research_and_Effectiveness/SFU_Data.jnz.

2. Saint Francis University, "Undergraduate Education," Saint Francis University website, accessed January 15, 2018, https://www. francis.edu/EducationDepartment/.

3. Jo Ann Carr, A Guide to the Management of Curriculum Materials Centers for the 21st Century: The Promise and the Challenge. (Chicago: ACRL, 2001).

4. Ibid., Carr, Guide to Curriculum Materials Centers.

5. Douglas Bleggi, e-mail message to author, January 12, 2018.

6. Mary Firestone, "Manipulatives in Education: Definition, Examples \& Classroom Applications," Study.com, accessed January 15, 2018, http://study.com/academy/lesson /manipulatives-in-education-definition -examples-classroom-applications.html.

7. "Overview of Learning Styles," Learning-styles-online.com, accessed January 15, 2018, https://www.learning-styles-online. com/overview/index.php.

8. Glenna Zeak, e-mail message to author, January 12, 2018.

9. Nancy Clarke, "The Roles and Functions of Curriculum Centers in Australia," The Australian Library Journal 40, (1991): 232-41.

10. Stephanie Ivory, e-mail message to author, January 12, 2018. $\approx$

\section{Upcoming ACRL e-Learning}

ACRL is offering a variety of webcasts this fall. Upcoming topics include:

Undergraduate Research and the Academic Librarian: Developing Programs for Undergraduate Researchers (Webcast, November 13, 2018)

Copyright and Open Educational Resources: Creation, Licensing, and Use (Webcast, December 6, 2018) 